\title{
Similarities in stakeholder identification of restoration targets in a semiarid area ${ }^{1}$
}

\author{
Mchich Derak $^{a}$, Lahcen Taiquib ${ }^{b}$ Antonio Aledo ${ }^{c}$, Jordi Cortina ${ }^{d}$ \\ a Direction Régionale des Eaux et Forêts et de la Lutte Contre la Désertification du Rif, \\ Avenue Mohamed V, BP 722, 93000, Tétouan, Morocco. \\ ${ }^{\mathrm{b}}$ Université Abdelmalek Essaadi, Faculté des Sciences de Tétouan, Avenue Sebta, \\ Mhannech II, BP 93002, Tétouan, Morocco. \\ ${ }^{c}$ University of Alicante, Department of Sociology 1, Ap. 99, 03080, Alicante, Spain. \\ d University of Alicante, Department of Ecology and IMEM, Ap. 99, 03080, Alicante, Spain.
}

Corresponding author: Mchich DERAK

Direction Régionale des Eaux et Forêts et de la Lutte Contre la Désertification du Rif. Avenue Mohamed V, BP 722, 93000, Tétouan, Morocco.

mchich78@gmail.com

00212666371927

\begin{abstract}
Ecological restoration is a suitable tool to revert the decline in the provision of ecosystem services in semiarid areas. Stakeholder opinion has been increasingly incorporated in ecological restoration strategies. However, the debate still exists whether the opinion of scientists and managers should be integrated together with that of local stakeholders in the decision making process. We assessed the restoration priorities in a semiarid area in North Morocco according to the opinion of 67 stakeholders, including scientists and managers, direct users and collaborators. The questions consisted in (i) ranking five categories of services in addition to economic benefits, and in (ii) comparing pairs of services within each category. We checked for both cardinal and ordinal inconsistency. The results showed an overall consensus about regulating and supporting services as the most valuable categories. More specifically, the most important services were erosion and flood control, soil fertility, water supply and species richness. The accuracy of the responses of the three groups was similar as the consistency for their judgments was not significantly different. Our results bring additional proof that the opinion of scientists, managers and local stakeholders should be considered of similar interest and accuracy when defining the most suitable restoration objectives.
\end{abstract}

\footnotetext{
${ }^{1}$ Derak, M., Taiqui, L., Aledo, A. and Cortina, J. (2016). Similarities in stakeholder identification of restoration targets in a semiarid area. Journal of Arid Environments 128: 30-39.
} 


\section{Introduction}

Ecosystem services represent the benefits that humans obtain from ecosystems (Millennium Ecosystem Assessment (MEA), 2005). Their global provision is declining due to the strong pressure exerted by human societies on ecosystems (Butchart et al., 2010; Reyers et al., 2009). Ecological restoration has the power to revert such decline, particularly for supporting and regulating services (Society for Ecological Restoration, 2004). Restoration actions often involve a broad range of stakeholders with diverse and often conflicting interests. Incorporating stakeholder choices and preferences has therefore become a necessity in ecological restoration strategies and actions (Bullock et al., 2011; De Groot et al., 2010).

Although local stakeholders are increasingly involved in projects dealing with the restoration of ecosystem services, few efforts have been made to address their preferences on ecosystem services from the perspective of their values, attitudes and beliefs (Martín-López et al., 2012). Furthermore, their opinion is rarely considered in the early phases of the projects, such as the definition of objectives and priorities of restoration actions (Khater et al., 2012). In most cases, scientists and managers seem more concerned about the acceptance of their own visions, rather than open to the perspectives and needs of other stakeholders (Menzel and Teng, 2009). A key factor behind this situation is that scientists and managers may differently understand and valuate ecosystem services in comparison to local stakeholders. In general, for scientists and managers, comprehension of ecosystem service notions pass through their scientific and technological experience, whereas for local stakeholders, it passes through their societal and cultural interactions with the immediate environment and their deep empirical knowledge, acquired over the years (McNeely, 2003; Reed, 2008). The two groups may also differ by their level of dependence on natural resources, their proximity to the considered area and their personal interests, among others. The main question here is whether these differences between the two groups may influence their choice of a suitable set of ecological restoration priorities. This topic has been widely discussed in the USA, Europe and South Africa, when assessing environmental and land management strategies (Chalmers and Fabricus, 2007; Goma et al., 2001; Lamarque et al., 2011; Payton et al., 2003; Strager and Rosenberger, 2006). The debate still exists whether the opinion of the two groups should be simultaneously integrated in environmental decisionmaking (Gadgil et al., 2003, Mauro and Hardison 2000; Nadasny, 1999).

In environmental decision making processes, the estimation of the weight (importance) of the elements under assessment, mostly alternatives and criteria, is a fundamental step. Pairwise comparison has been frequently selected as the weighting procedure (Malczewski, 1999; Romero, 1996). This method allows comparing elements one by one, and assigning a judgment value along the 1-9 scale to each comparison, as recommended by Saaty (1980). The weight of each element is then mathematically computed. Pairwise comparisons offer the possibility to check the harmony and goodness of the preferences by computing the consistency of the emitted judgments. The consistency value is a useful statistical measure to ensure that the emitted judgments are closer to being logically made than randomly performed, and consequently that the corresponding weights are acceptably derived (Bozóki and Rapcsák, 2008; Siraj, 2011). The consistency of the preferences expressed by scientists and managers in comparison to local stakeholders has been analyzed in many studies focused on environmental issues such as forest management planning (Kangas, 1994), energetic policies' implications (Noble, 2004), and selection of sites for waste disposal (De Feo and De Gisi, 2010). In ecological restoration, such comparative analysis is still rare.

In Morocco, new planning strategies consider local populations as a key factor in socioeconomic development. For example, in the forest sector, the National Forest Program adopted in 1998 stresses the importance of the adhesion of local populations to sustainable 
management programs (Moroccan Forest Ministry, 1999). Under these considerations, the Moroccan Administration has recently developed several agricultural and forest projects to restore degraded semiarid lands (Benbrahim et al., 2004). There are many experiences of the active involvement of stakeholders in development projects, including the GEF-Rif project (Melhaoui, 2002) which focused on the participative management of forest ecosystems in the Rif region, North Morocco, and the Demonstration Project on Strategies to Combat Desertification in Arid Lands with Direct Involvement of Local Agro-pastoral Communities in Tansift, south Morocco (Mulas et al., 2012). However, this is not a general trend, and the local community is still barely involved in agricultural and forest projects, especially in early stages of project formulation. Usually, local beneficiaries are asked to accept or refuse a specific package of actions, with no possibility to discuss their pertinence, level of priority or execution mode (International Bank for Reconstruction and Development, 2006). This may partly explain why many ecological restoration actions, such as reforestation programs, are often subject to massive objection by local populations who rarely recognize the positive impacts of these actions (Boujrouf, 1996; Moufaddal, 2007). There is an urgent need to develop more integrative restoration programs which consider opinions from different components of the community. Additionally, the need still exists for easy and flexible methods that elicit stakeholder preferences on ecosystem services in a manner that considers the various factors related to Moroccan semiarid rural areas such as poverty, analphabetism and high dependence on natural resources.

The main objectives of this study are: (i) to evaluate the environmental and socioeconomic priorities in a Moroccan semiarid area, expressed in terms of ecosystem services by a representative sample of stakeholders, (ii) to compare the priorities of scientists and managers and those of local stakeholders, and assess the consistency of the judgments of both groups, and (iii) to propose a framework for an integrative definition of ecological restoration targets.

\section{Material and methods}

\subsection{Study area}

Our study was conducted at Béni Boufrah valley $\left(34^{\circ} 58^{\prime}-35^{\circ} 10^{\prime} \mathrm{N} ; 4^{\circ} 14^{\prime}-4^{\circ} 25^{\prime} \mathrm{W}\right)$ located in the Central Rif, $55 \mathrm{~km} \mathrm{~W}$ of Al Hoceima, and covering $163 \mathrm{~km}^{2}$ (N Morocco, Fig. 1). Climate is semiarid Mediterranean with cold and mild winters. Rainfall is irregular and often stormy. Topography is abrupt and the valley is longitudinally crossed by a river, also called Béni Boufrah, which has a broad riverbed covered with gravels. Béni Boufrah is one of the Moroccan neediest areas (poverty rate of $18 \%$ ) and it is characterized by high population size (10298 inhabitants), high demographic density (65 inhabitants per $\mathrm{Km}^{2}$ ), large household size (6.6 inhabitant per household), high rates of illiteracy (57\% for people over 10 years) and a serious problem of rural exodus (Moroccan General Census, 2004; Regional Forest Administration of NE Morocco, 2012). The proportion of active population is high, as $57 \%$ of the people are between 15 and 59 year-old. The gender structure is equilibrated, with $52 \%$ of men and $48 \%$ of women.

The productive system is polyvalent and it is mainly based on agriculture, animal husbandry and sea fishing (Al Karkouri et al., 2002). Subsistence farming delivers low yields as a consequence of land fragmentation, rough terrain, high soil stoniness, and lack of irrigation and mechanization. The dominant crops are rainfed cereals, mainly barley and wheat, and fruit trees, mostly almond and olive. Béni Boufrah is known by a cactus cultivar (Opuntia ficus-indica (L.) Mill. var. Dellahia), which has gained an increasing cultural and commercial value at regional and national scales. Animal husbandry (mostly extensive) is based on sheep and goats. Grazing pressure has been recently reduced as a result of successive droughts, rural exodus and abandonment of traditional agro-pastoral systems. Sea fishing has always constituted the main economic activity in coastal villages, but due to its artisanal nature, the contribution of this activity to monetary incomes and employment is limited. The 
area hosts other economic activities of lower importance such as harvesting of aromatic and medicinal plants, beekeeping, eco-tourism, among others.

Béni Boufrah forests are dominated by Barbary Red Cedar (Tetraclinis articulata Vahl Masters). In addition to its ecological and socioeconomic importance, Tetraclinis forest plays a relevant role in local customs and cultural identity. However, in the beginning of the $20^{\text {th }}$ century, Tetraclinis forests have been intensely decimated as a consequence of illicit cutting and expansion of agricultural land (Pascon and Wusten, 1983). Forest decline has been accompanied by other forms of natural resource degradation, as soil erosion, loss of soil fertility and increased risk of flooding. Since the 1960s, the Moroccan Administration undertook several projects aimed at restoring the landscape in this region, including the DERRO project (Economic and Rural Development of the Western Rif, 1961-1972). Implemented measures encompassed the plantation of Pinus halepensis on terraces and almond trees on agricultural fields (Fig. 2), and a wide variety of actions to control erosion (Al Karkouri et al., 2002; Pascon and Wusten, 1983). Despite these initiatives, the provision of ecosystem services has steadily decreased as human pressure and degradation increased (Al Karkouri, 2003).

\subsection{Establishment of a multi-stakeholder platform}

In our study, we use the term "stakeholder" to refer to "those people who will be affected or may have some influence on a decision" (Freeman, 1984; Wilcox 2003). Following this definition, we established a multi-stakeholder platform, including people involved in ecological restoration programs, such as reforestation of degraded lands and regeneration of natural forest stands. There is no standard procedure for setting the number of stakeholders in such platforms, as it depends upon the objectives of the assessment and available time and resources, and thus it is context and case specific (Noble, 2004). Thus, rather than applying a sampling rate, we aimed at obtaining a representative sample regarding gender, age, education level, socio-professional profile, dependence on natural resources, proximity to the area, involvement and influence on decisions linked to land use management, and possible engagement in future ecological restoration interventions (Table 1). Furthermore, we followed a chain referral protocol until saturation (Bautista and Orr, 2011), in the sense that we initially interviewed a short list of potential stakeholders, who provided information and referrals to other stakeholders. The process was iterated until referrals became redundant. We contacted stakeholders from different organizations and institutions but also seek to reach traditionally marginalized individuals and peripheral stakeholder groups.

In total, we interviewed 67 individuals with an average age of 47 years. As much as $55 \%$ of the stakeholders were older than that. The low proportion of women $(21 \%)$ was the result of local traditions, which limit inter-gender contacts and preclude women to hold positions in public Administrations, Universities and research centres. Of the stakeholders, $18 \%$ were illiterate and $40 \%$ had primary or secondary school level. To create a successful mix of stakeholders, Scheele (1975) suggests considering three groups of people: experts, those who have an applicable specialty or relevant experience; facilitators, those who have skills in stimulating social participation and can supply alternative global views of the culture and society; and true stakeholders, those who are or will be directly affected by an action. In Béni Boufrah, we divided the stakeholder platform into three groups, according to their involvement in decision making processes linked to ecological restoration: (i) scientists and managers, (ii) collaborators and (iii) direct users (Table 1). The two later groups were considered local stakeholders. Scientist and managers have high scientific and technological knowledge, especially in the field of ecological restoration and landscape management. Most of them have a relatively high income and belong to middle social classes. They live outside the study area and their experience in environmental activities is large. They may have administrative or scientific responsibilities in natural resource management. Collaborators commonly hold secondary or higher education degrees, and their knowledge on the 
principles of ecological restoration is scarce. Almost half of them belong to middle social classes and live in the area. This group is familiar with environmental activities, and act as an intermediaries between the other two stakeholder groups in the implementation of sociodevelopment actions. Direct users have low to very low education level. Most of them have low incomes and suffer economic difficulties. They all live in the area and have a strong dependence on the provision of local natural resources. Few of them have participated in previous environmental activities.

\subsection{Ecosystem services weighting}

We identified five land uses that reflect the overall situation of the study area and population priorities. Land uses consisted of pine afforestation, almond tree plantations, Tetraclinis forests, shrublands dominated by lavender (Lavandula dentata L.) and thyme (Thymus vulgaris L.), and cactus groves (Fig. 1 and 2). The contribution of these land uses to the enhancement of human well-being was assessed by estimating economic benefits (employment supply, monetary incomes) and the provision of five categories of ecosystem services (MEA, 2005): supporting (soil fertility, primary production), regulating (erosion control, flood control, local climatic regulation), provisioning (biomass production, forage productivity, food supply, aromatic and medicinal plants, water retention), cultural (aesthetic value, traditional value) and biodiversity (species richness, plant endemism, game abundance). This set of 17 services was selected on the basis of data availability, expert advice and our own experience in Béni Boufrah and similar semiarid areas (Derak and Cortina, 2014). Furthermore, we asked six experts in hydrology, forestry and sociology, as well as representatives of governmental offices and environmental organizations. We also asked the local population in informal meetings.

The weights of categories and services were obtained from stakeholder opinions. A series of 15-20 min interviews were held between November $12^{\text {th }}, 2012$ and June $9^{\text {th }}, 2013$. All interviews were carried out by the same facilitator through direct and individual meetings to minimise bias. Interviews were performed in Arabic or French, according to each stakeholder' education level and choice. Each service and indicator was succinctly introduced and illustrated to each stakeholder by showing him or her a set of 41 photos taken in the region. We used simple language that could be easily understood by all stakeholders. The questionnaire had close-ended questions. However, stakeholders were free to explain and justify their choices. Additional information was recorded aside.

We used a structured questionnaire divided into two parts. In the first part, the 67 stakeholders were asked to rate the six categories of ecosystem services by assigning a value from 1 to 6 to each one according to its importance in the enhancement of the human well-being in the area. The value of 6 corresponded to the most important category, and 1 to the least one. From the assigned value, we deduced the weight of each category. In the second part, stakeholders were asked to compare pairs of services within the same category. As the 1-9 scale recommended by Saaty (1980) can be complicated for such weighting exercise (Kangas, 1994; Strager and Rosenberger, 2006), and in order to ease comparisons, especially for illiterate stakeholders, we adopted a 1-3-5 scale. The value of 1 was assigned when two services had the same importance. The outcome of the comparison was 3 when one service was moderately more important than the other. Finally, stakeholders assigned the value of 5 when one service was greatly more important than the other. The pairwise comparisons were limited to the provisioning services, biodiversity and regulating services and led to $5 \times 5,3 \times 3$ and $3 \times 3$ reciprocal matrices, respectively. For these three categories, we first checked the consistency of the pairwise comparisons in order to prevent possible priority violations, i.e. contradictions between the emitted judgments and the corresponding weights (Ali et al., 1986). We checked for both cardinal and ordinal inconsistencies. 
Cardinal inconsistency was calculated using Saaty Consistency Ratio (CR). According to Saaty (1980):

$$
\mathrm{CR}=\mathrm{Cl} / \mathrm{RI}
$$

Where $\mathrm{Cl}$ is the consistency index given by the equation:

$$
\mathrm{Cl}=\left(\lambda_{\max }-n\right) /(n-1)
$$

$\lambda_{\max }$ is the largest eigen-value, and $\mathrm{n}$ is the order of the matrix. $\mathrm{RI}$ is the Random Index which corresponds to the average value of $\mathrm{Cl}$ for randomly generated comparisons. $\mathrm{CR}=0$ when comparisons are perfectly made, and $\mathrm{CR}=1$ when they are carried out randomly. A CR of 0.10 or less is considered as acceptable. Otherwise, the reciprocal matrix is recommended to be reconstructed to resolve inconsistency problems (Saaty, 1980). The CR is related to Saaty scale (Bozóki and Rapcsák, 2008). As our scale enclosed only the values 1, 3 and 5, whose interpretation is different than in the 1-9 scale case, we adjusted the CR for the $3 \times 3$ and $5 \times 5$ matrices. For each dimension, and using the Matlab R2011a program (The Math Works, Inc., USA), we generated 500 pairwise comparison matrices (as performed by Saaty) whose elements were randomly chosen from the scale $1 / 5,1 / 3,1,3,5$. We then computed the average value of $\lambda^{*}$ max , and consequently deduced the adjusted Random Index $\mathrm{RI}^{*}$. As shown in Table $2, \mathrm{RI}^{*} \approx 1 / 2 \mathrm{RI}$ for both $3 \times 3$ and $5 \times 5$ matrices, which means that the pairwise comparisons made by stakeholders in our exercise were done according to a set of random pairwise comparisons twice thinner than the Saaty set. We labelled our adjusted Consistency Ratio $\mathrm{CR}^{*}$ to distinguish it from the original Saaty $\mathrm{CR}$.

Ordinal inconsistency was measured using the transitivity principle and the dissonance measure. Transitivity occurs when the preference of $A$ over $B$, and B over $C$ carries a preference of $A$ over $C$. Otherwise, a three-way cycle appears. We used the number of threeway cycles $L$ as a measure of transitivity (Kendall and Smith, 1940). A matrix is transitive when $L=0$ and intransitive when $L \neq 0$. Furthermore, we used the dissonance value $\psi$ of ordinal violation between a judgment and the corresponding indirect judgments (Siraj, 2011). For an $n$ matrix, if an element $E_{i}$ was preferred to $E_{j}$ (implying the correspondent judgment $a_{i j}>1$ ), then the condition $a_{i k} a_{k j}>1$ had to be met for all $k=1,2 \ldots n$. Otherwise, a latent violation occurred.

As reported above, when the inconsistency of pairwise comparisons is relatively high $(\mathrm{CR}>$ 0.10 corresponding to $\mathrm{CR}^{*}>0.2$ ), stakeholders should be asked to revise their inconsistent judgments and rectify them. As it was not possible to repeat the exercise with most stakeholders and in order to avoid confusing illiterate stakeholders, we decided to computationally correct the inconsistent judgments. To do this, we applied different prioritization methods to elicit the ecosystem services weights for the three fore-mentioned categories: Eigen Vector Method for matrices with $C R^{*} \leq 0.2$, Direct Least Square Method for those with $\mathrm{CR}^{*}>0.2$ and $\Psi=0$, and Multi-Objective Method for those with $\mathrm{CR}^{*}>0.2$ and $\psi>0$ (Siraj, 2011). The calculations were performed using the PriEsT program (School of Computer Science, University of Manchester, UK; www.sourceforge.net/projects/priority/files/).

It is important to stress that we used a different weighting method for each hierarchy level. A preliminary test showed that pairwise comparisons of the six categories of ecosystem services led to confusions, as each category encloses a wide variety of services that were hardly remembered by many interviewees. Furthermore, such exercise would require 15 additional pairwise comparisons which would make the process heavy and annoying. For that reason, we asked stakeholders to simply rate the six categories of ecosystem services, as explained above.

For both categories and service weighting level, stakeholders were considered as acting in their own right. Thus, the three socio-professional group weights were established by calculating the arithmetic mean of the individual weights (Forman and Peniwati, 1998). 


\subsection{Statistical analysis}

As the weights of the six categories of ecosystem services were inter-dependent, we used the non-parametric Friedman test followed by Wilcoxon post-hoc test to check for significant difference between the six categories. The same tests were used to check for significant differences between the weights of services within the same category, when categories contained more than two services. For categories with two services, we used Wilcoxon test. The difference between the three groups of stakeholders in terms of $\mathrm{CR}^{*}$ and $\psi$ values was checked using a one-way ANOVA followed by Tukey HSD post-hoc test. All statistical analyses were performed using SPSS 13.0 package (SPSS Inc., Chicago, USA).

\section{Results}

\subsection{Ecosystem services weights}

According to the overall opinion of the 67 stakeholders, regulating and supporting services were perceived as the most important categories. Provisioning services occupied an intermediate position whereas biodiversity, economic benefits and cultural services occupied the last position (Table 3). At the service level, results showed that some services were greatly more appreciated to others within a same category: erosion and flood control for regulating services, soil fertility for supporting services, water supply for provisioning services, species richness for biodiversity, and traditional value for cultural services.

Almost the same tendency was obtained for the three groups of stakeholders, albeit small disagreements merit to be mentioned. At the category level, scientists and managers considered biodiversity of an intermediate importance as well as provisioning services, while local stakeholders, i.e. users and collaborators, attached the least importance to biodiversity together with economic benefits and cultural services. At the service level, only users considered soil fertility as significantly more important than primary production. In contrast to collaborators and users, scientists and managers considered plant endemism as important as specific richness, and landscape traditional value of similar importance to aesthetic value.

\subsection{Inconsistency analysis}

Cardinal inconsistencies measured by the consistency ratio $\mathrm{CR}^{*}$ showed that some stakeholders were cardinally more consistent than others when comparing services within the provisioning, biodiversity and regulating categories (Fig. 2a). Comparisons ranged from fully consistent $\left(\mathrm{CR}^{*}=0\right)$ to extremely inconsistent $\left(\mathrm{CR}^{*}=2.28\right)$ and the majority of $\mathrm{CR}^{*}$ values were below 0.50 . In average terms, none of the three stakeholder groups was significantly more cardinally consistent than the others $\left(F_{2,64}=1.328, p=0.272 ; F_{2,64}=0.533, p=0.589\right.$ and $\mathrm{F}_{2,64}=1.395 ; p=0.255$, respectively for regulating, provisioning and biodiversity categories). However, when analysing undesired outlying inconsistency $\left(1<\mathrm{CR}^{*}<1.5\right)$ and extreme inconsistencies $\left(\mathrm{CR}^{*}>1.5\right)$, collaborators showed a slight weakness expressed by two outliers and two extreme inconsistencies.

Ordinal inconsistency was acceptable for the 67 stakeholders, as the transitivity principle was respected $(L=0)$ for the three categories of services. Nevertheless, the other measure of ordinal inconsistency, the dissonance value, showed that some stakeholders could maintain a logical link between all pairwise comparisons of services within a same category, but others could not. Thus latent violations were null $(\Psi=0)$ to high $(\Psi=0.67)$ and the majority of $\Psi$ values were below 0.15 (Fig. 2b). In average, ordinal inconsistency was significantly similar for the three groups of stakeholders $\left(F_{2,64}=1.466, p=0.239 ; F_{2,64}=3.083, p=0.055\right.$ and $\mathrm{F}_{2,64}=1.410, p=0.252$, respectively for regulating, provisioning and biodiversity categories). Furthermore, the eight cases of extreme ordinal inconsistencies $(\Psi>0.33)$ were almost equally distributed among the three groups of stakeholders.

Results showed also that stakeholders experienced problems of cardinal and ordinal inconsistency when comparing elements of biodiversity. In fact, among the seven cases of outliers and extreme values of $\mathrm{CR}^{\star}$, five cases involved comparisons within the biodiversity 
category. Furthermore, biodiversity showed the highest variability of $\Psi$ values, especially for collaborators and users. Provisioning services resulted in being less problematic regarding the consistency of comparisons as they showed low variability and no extreme values for both $\mathrm{CR}^{*}$ and $\Psi$ measures.

\section{Discussion}

\subsection{Stakeholder preferences regarding ecosystem services}

According to Rodriguez et al. (2006), human preferences for ecosystem services are generally inclined towards provisioning services, followed by regulating, cultural and supporting services. These authors argued that the heavy emphasis on provisioning services could be the consequence of their value being more tangible and easily identifiable by our societies, whereas the economic value of regulating, cultural and supporting services are more difficult to quantify. In contrast, stakeholders in Béni Boufrah attached the most critical importance to regulating and supporting services, particularly erosion control, flood management and soil fertility. Provisioning services, especially water and food supply occupied only an intermediate position, whereas biodiversity, economic benefits and cultural services were considered as the least important categories. Béni Boufrah is representative of the many valleys of the Central Rif characterized by active erosive and flooding processes that lead to serious danger to human lives, big damages on infrastructures, and a negative impact on soil fertility and agricultural and pastoral productivity (Al Karkouri, 2003; El Khattabi, 2001). That is why stakeholders placed regulating and supporting services at the top of their preoccupations. Most of them stated that, if these two categories of services were improved, provisioning and cultural services, as well as biodiversity, would gain increasing importance. Similarly, ecosystems would be perceived as effectively contributing to the creation of employment opportunities and the diversification of income sources.

The highest importance placed on regulating and supporting services confirms previous studies carried out in semiarid Mediterranean areas with similar biophysical conditions. For instance, in Southern and South-eastern Spain, stakeholders attached the highest priority to regulating services and soil formation (Castro et al., 2011; Derak and Cortina, 2014; MartínLópez et al., 2012). In semiarid areas of Morocco and Spain, the provision of regulating and supporting services has been a priority, favouring the deployment of conservative agricultural practices such as terracing (Butzer, 2005; García-Llorente et al., 2012; Laouina et al., 2006). However, human dependence on local hydrological and agricultural issues is more important in the former country. Thus, semiarid areas in North Morocco face increasing human pressure, and conversion of forest and woodland areas to agricultural lands is common (Al Karkouri et al., 2006), whereas abandonment of agricultural land is the dominant process in the northern rim of the Mediterranean basin (Rodríguez-Aizpeolea and Lasanta-Martínez, 1992).

The three groups of stakeholders showed similarities regarding the most valuable categories and specific sets of ecosystem services. However, slight differences in their choices could be detected, leading to two major sets of opinions, one formed by scientists and managers, and the other by local stakeholders represented by collaborators and users. Scientists and managers showed awareness on the role of biodiversity for human well-being, and acknowledged its intimate relation with other ecosystem traits. In contrast, local stakeholders considered that biodiversity was not amongst their urgent necessities. This lack of awareness probably resulted from a deficient understanding of the concept of biodiversity. Previous studies have found that stakeholder preferences towards biodiversity were influenced by socioeconomic and cultural level (Castro et al., 2011; Martín-López et al., 2007a). Our results support these findings, as they showed that local stakeholders (particularly direct users) had lower educational level, lower experience with environmental 
activities, and higher dependence on local natural resources than scientists and managers, probably as a consequence of their lower economic possibilities (Table 1).

Stakeholder preferences also relied on their place of residence, and thus on the physical attachment to the area (Martín-López et al., 2012). In our case, scientists and managers, most of them living outside Béni Boufrah (Table 1), showed less awareness of the specific identity of the area, and the traditional uses made from natural resources such as Tetraclinis forests and shrublands. That is probably why they considered traditional value as important as aesthetic value. Similarly, direct users, who are mostly involved in agricultural activities, considered soil fertility as significantly more important than primary production, which illustrates their deep knowledge of the land conditions. This result is in agreement with the study by Jungerius et al. (1985) who reported that farmers in Béni Boufrah were aware of the poor condition of their land and the need to improve soil fertility by using manure.

The observed minor disagreements between scientists and managers and local stakeholders confirm previous studies which highlighted that, in comparison to external experts, local stakeholders were more concerned by the provision of specific services that were essential for their life, rather than broad issues such as biodiversity conservation (Lamarque et al., 2011; Strager and Rosenberger, 2006). As underlined by Martín-López et al. (2012), these different perceptions allow integrating a wide range of ecosystem services into management decisions. This aspect has been considered in many approaches dealing with technological and scientific research. For example, in the post-normal science approach, Funtowicz and Ravetz (2000) highlighted that the decision making process should involve a wide range of people affected or interested by a specific problem, in addition to people with institutional accreditation. These authors reported that people directly affected by an environmental problem may likely have a deeper conscience of its symptoms and a higher interest on it, than those less concerned by this problem. Considering the wide range of social interests and aspirations towards ecosystem services is a preliminary step towards preventing possible conflicts in landscape planning (Anton et al., 2010).

\subsection{Comparative consistency of stakeholders judgments}

In environmental assessment, local skills and local knowledge can complement those of professional scientists and managers (Elbroch et al., 2011; González et al., 2009). However, there is still a debate regarding the comparative accuracy of the preferences emitted by scientists and managers vs. local stakeholders. In previous studies based on pairwise comparisons of environmental and socioeconomic criteria, many authors reported that scientific and professional experts showed higher consistency in their opinions than local stakeholders (Kangas, 1994), while others found no difference in consistency between the two groups of stakeholders (De Feo and De Gisi, 2010; Noble, 2004). In our study, averages of cardinal and ordinal consistency values for local stakeholders (collaborators and users) were similar to those of scientists and managers. Furthermore, the transitivity principle was not broken by any of the 67 stakeholders, and the few cases of extreme inconsistencies (particularly ordinal ones) were equally distributed among all groups. All of these results converged in that, despite of the low scientific and technological knowledge of local stakeholders, they were able to express their preferences in terms of ecosystem services in a consistent way, as scientists and managers did. Similar accuracy between the two groups of stakeholders supports the idea that the judgment of scientist and manager should not be considered as more credible than that of local stakeholders (Noble, 2004).

Knowledge is not the only factor behind inconsistencies in judgments. Inconsistencies rely also on personal and psychological traits such as the lack of concentration during the judgment process (Siraj, 2011; Sugden, 1985), the degree of motivation and personal involvement during the interview (Accorsi et al., 1999), the experience with exercises which require making logically related judgments (Noble, 2004), and the way stakeholders are approached and the language used by the interviewer (Goma et al., 2011). Questions are 
often formulated in scientific manners which may not be readily understood by some stakeholders. This may increase the likelihood of additional methodological bias. We tried to reduce this type of bias by appointing a single facilitator, performing the interviews in Arabic and French, bringing photographic illustrations, and adopting the 1-5 scale for pairwise comparisons. This strategy probably contributed to maintain the inconsistency level low and similar for the three stakeholder groups, which is crucial to ensure the same level of accuracy to the estimations of the weights of the different ecosystem services.

The consistency of judgments reflects the extent to which stakeholders understand the problem and are knowledgeable of the criteria involved (Noble, 2004). In our case, comparisons involving biodiversity led to cases of outliers and extreme inconsistencies. During the interviews, many users and collaborators showed difficulties to understand the concept of biodiversity, particularly endemic and threatened flora, which probably lead to a problem of inconsistency. As highlighted by previous studies (Martín-López et al., 2012; Sodhi et al., 2010), local stakeholders understanding of the concept of biodiversity could be enhanced by environmental education. Although provisioning services involved a higher number of comparisons (ten pairwise comparisons), which could lead to higher probability of errors, this category showed a very low level of inconsistency as stakeholders felt comfortable to compare pairs of tangible goods such as water, food, forage and biomass. This result confirms previous findings that the more familiar the stakeholders are with the criteria under assessment, the more consistent are their comparisons (Kangas, 1994).

\subsection{Implications for ecological restoration}

One of the key factors of the ecological restoration success in Morocco is the active implication of all stakeholders in all phases of the process, including the definition and approval of ecological restoration objectives (Regato et al., 2009). Our study followed this approach, and incorporated the opinion of scientists, managers and local stakeholders on the provision of ecosystem services linked to ecological restoration alternatives. Although there were slight differences between these groups, there was a general agreement on the need to focus ecological restoration targets on regulating and supporting services, particularly erosion control, flood management and soil fertility. Soil conservation is not a recent issue in the Central Rif, as it was considered as an extremely urgent priority in the late 1950s and early 1960s, and was one of the main reasons for the adoption of the integrated DERRO project (Avril, 1966; Perry, 2014). Our results show that, despite the efforts of this and other development projects, people are still concerned by hydrological and agricultural issues.

In ecological restoration, both formal and local knowledge are complementary, and their combination can be beneficial for sustaining the delivery of multiple ecosystem services (Khater et al., 2012). In this sense, our results showed that each group is called to learn from the other in order to capture the entire range of ecological restoration targets. Indeed, while local stakeholders showed a relative lack of awareness and understanding of the concept of biodiversity, scientists and managers showed limited knowledge of traditional land uses and agricultural conditions. Furthermore, our results suggest that there is no risk of inconsistency when integrating priorities expressed by local stakeholders, and that the reliability of their preferences can be guaranteed, especially if suitable methodologies are adopted. By doing so, all stakeholders may perceive that they are indeed influencing decision making processes and the outcomes of ecological restoration programs.

A further step towards adopting structured decisions on the most suitable interventions for ecological restoration is to integrate social opinions and biophysical factors. Thus, stakeholder weights on ecosystem services can be combined with the empirical value (performance) of each service for each land use to obtain an integrative evaluation. By applying appropriate multi-criteria analysis, it may be possible to determine if restored landscape units respond more adequately to stakeholder needs and aspirations than unrestored ones, and evaluate their contribution to society well-being by enhancing the bulk of 
ecosystem services (Derak and Cortina, 2014; Fontana et al., 2013). Aggregation of scientific knowledge and human needs and values may enhance the efficiency and sustainability of ecological restoration practices, and thus increase the likelihood of their success.

\section{Conclusion}

In the present study, we adopted a participative approach to identify ecological restoration targets in a semiarid area in northern Morocco within the framework of biodiversity and ecosystem service assessment. Our results showed that scientists, managers and local stakeholders agreed in the need to focus restoration efforts on regulating and supporting services. We also found that knowledge and experience of all groups of stakeholders are complementary, and their combination may contribute to integrate different social perceptions and needs in the decision making process. The integration of all groups of stakeholders did not increase inaccuracy, as the level of inconsistency of local stakeholders' judgments when comparing pairs of services was similar to that of scientists and managers. We think that participative ecological restoration in semiarid areas requires a shift away from a top-down approach that perceives local stakeholders as secondary partners or receivers of decisions. Local stakeholders should be given a stronger share in decision making, while maintaining an atmosphere of equity, transparency and mutual respect, which may contribute to social acceptability of the restoration actions and hence, to their success. 


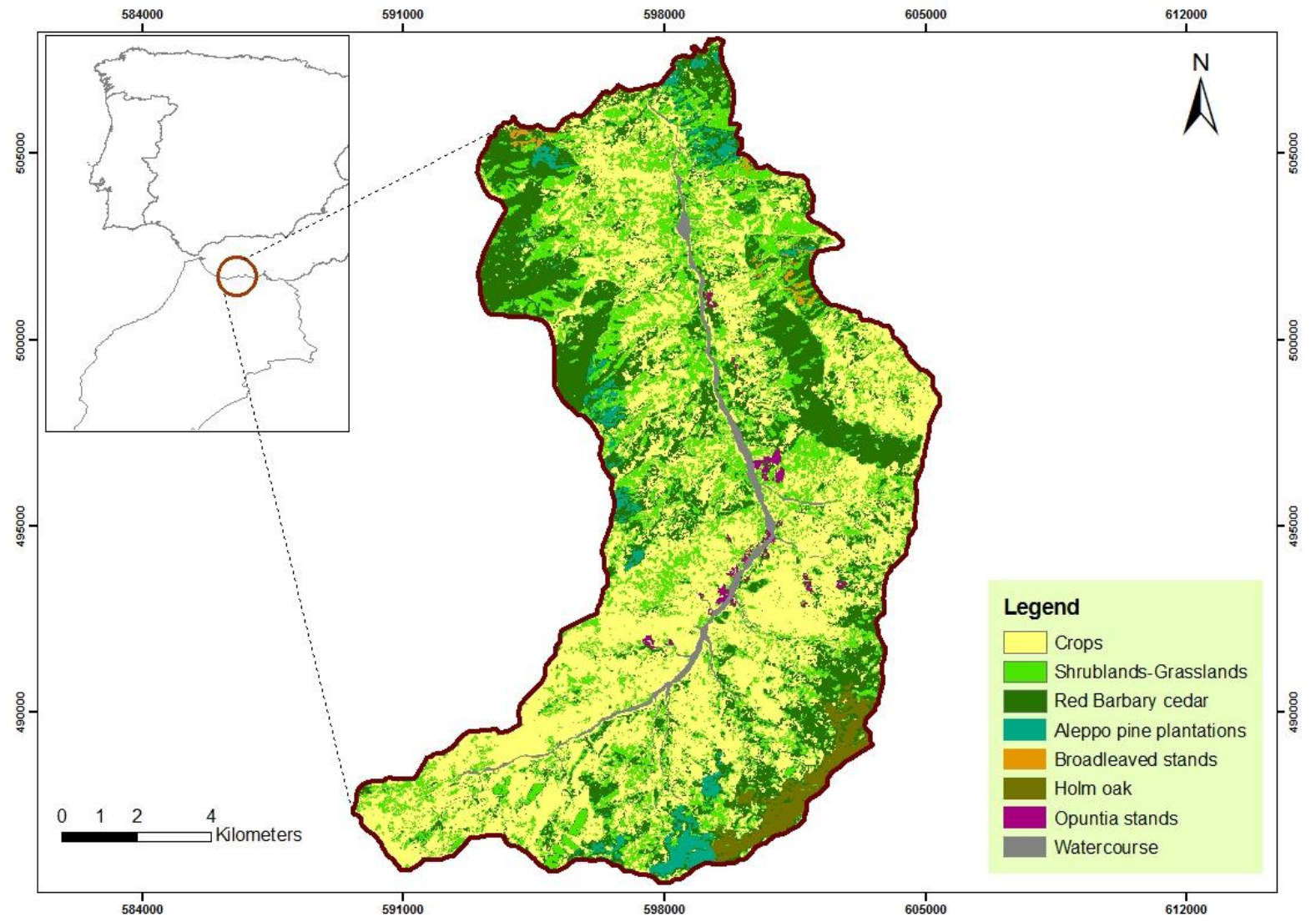

Figure 1. Location and main land uses of the Béni Boufrah catchment. The inset shows northern Morocco. 


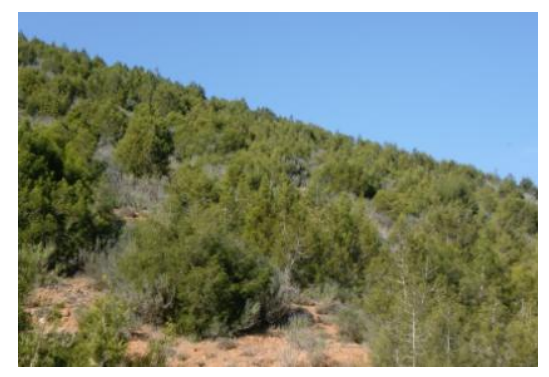

Tetraclinis forest

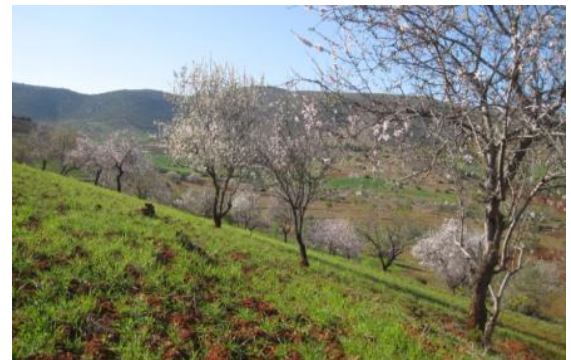

Crops

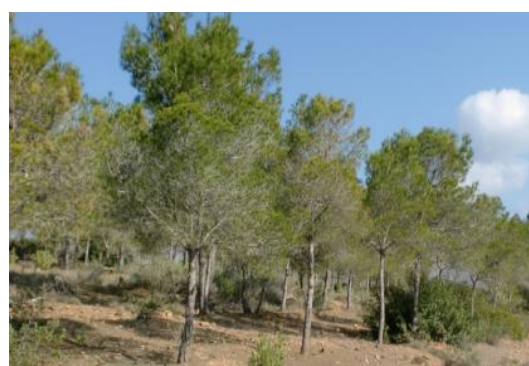

Pine afforestation

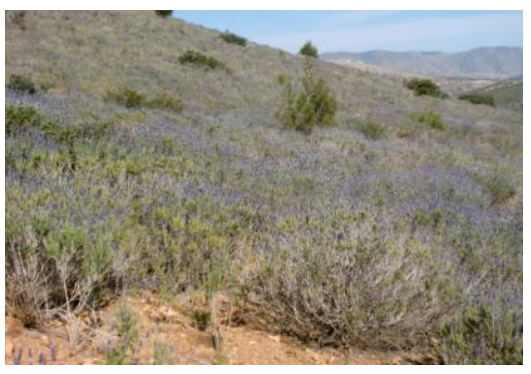

Shrublands

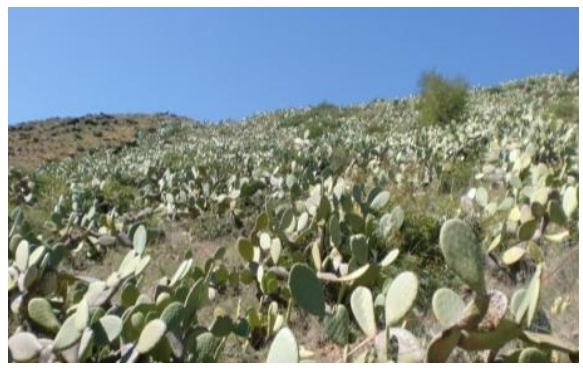

Cactus grove

Figure 2. Photographic illustration of the assessed land uses in the Béni Boufrah area. 
Table 1. Composition and main characteristics of the stakeholder platform established to evaluate ecosystem services in Béni Boufrah ( $\mathrm{N}$ Morocco). $\left(^{\star}\right)$ According to Moroccan High Commissary of Planning, social middle class refers to the central range of the social distribution of incomes or consumption expenditure, with an average income of US\$530 (data of 2007).

\begin{tabular}{|c|c|c|c|c|c|c|c|c|c|c|}
\hline Groups & Stakeholders & $\begin{array}{c}\text { Number of } \\
\text { people } \\
\text { interviewed }\end{array}$ & Subtotal & $\begin{array}{c}\text { Average } \\
\text { age } \\
\text { (years) }\end{array}$ & $\begin{array}{c}\text { Educational } \\
\text { level }\end{array}$ & $\begin{array}{l}\text { Proportion of } \\
\text { stakeholders } \\
\text { as middle } \\
\text { class }^{(*)}(\%)\end{array}$ & $\begin{array}{l}\text { Place of } \\
\text { residence }\end{array}$ & $\begin{array}{c}\text { Dependen } \\
\text { ce on local } \\
\text { natural } \\
\text { resources }\end{array}$ & $\begin{array}{c}\text { Stakeholders with } \\
\text { previous } \\
\text { experience in } \\
\text { environmental } \\
\text { participation (\%) }\end{array}$ & $\begin{array}{l}\text { Responsibility } \\
\text { in decision }\end{array}$ \\
\hline \multirow{3}{*}{$\begin{array}{l}\text { Scientists \& } \\
\text { managers }\end{array}$} & Researchers, University Faculty & 8 & \multirow{3}{*}{19} & \multirow{3}{*}{45} & \multirow{3}{*}{ University } & \multirow{3}{*}{$89 \%$} & \multirow{3}{*}{ Outside } & \multirow{3}{*}{ Low } & \multirow{3}{*}{$89 \%$} & \multirow{3}{*}{ High } \\
\hline & $\begin{array}{l}\text { Forest Administration } \\
\text { Agricultural Administration }\end{array}$ & $\begin{array}{l}6 \\
4\end{array}$ & & & & & & & & \\
\hline & Hydrological department & 1 & & & & & & & & \\
\hline \multirow{7}{*}{ Collaborators } & Local authority & 2 & \multirow{7}{*}{20} & \multirow{7}{*}{48} & \multirow{7}{*}{$\begin{array}{c}\text { Secondary to } \\
\text { university }\end{array}$} & \multirow{7}{*}{$65 \%$} & \multirow{7}{*}{ Mainly local } & \multirow{7}{*}{ Medium } & \multirow{7}{*}{$85 \%$} & \multirow{7}{*}{ Low } \\
\hline & Municipal representatives & 3 & & & & & & & & \\
\hline & NGO members & 6 & & & & & & & & \\
\hline & Touristic facilitators & 2 & & & & & & & & \\
\hline & Primary school professors & 1 & & & & & & & & \\
\hline & Local developers & 2 & & & & & & & & \\
\hline & Other functionaries & 4 & & & & & & & & \\
\hline \multirow{6}{*}{ Direct users } & Farmers & 6 & \multirow{6}{*}{28} & \multirow{6}{*}{47} & \multirow{6}{*}{$\begin{array}{l}\text { Illiterate to } \\
\text { secondary }\end{array}$} & \multirow{6}{*}{$11 \%$} & \multirow{6}{*}{ Local } & \multirow{6}{*}{ Very high } & \multirow{6}{*}{$14 \%$} & \multirow{6}{*}{ Low } \\
\hline & Members of cooperatives & 8 & & & & & & & & \\
\hline & Fishermen & 5 & & & & & & & & \\
\hline & Hunters & 1 & & & & & & & & \\
\hline & Lumberjacks & 1 & & & & & & & & \\
\hline & Other local inhabitants & 7 & & & & & & & & \\
\hline
\end{tabular}

Table 2. Average eigenvalue $\lambda_{\max }$ and Random index RI calculated for pairwise comparison matrices of dimension 3 and 5, using 1-9 Saaty scale and 1-5 scale.

\begin{tabular}{c|cc|cc}
\hline \multirow{2}{*}{ Order of matrix } & \multicolumn{2}{|c|}{ Using 1-9 scale } & \multicolumn{2}{c}{ Using 1-5 scale } \\
\cline { 2 - 5 } & Average $\lambda_{\max }$ & $\mathrm{Rl}$ & Average $\lambda^{*} \max$ & $\mathrm{RI}^{*}$ \\
\hline 3 & 4.16 & 0.58 & 3.57 & 0.29 \\
\hline 5 & 9.48 & 1.12 & 7.28 & 0.57 \\
\hline
\end{tabular}


Table 3. Weights (means \pm SE) of categories and services derived from the preferences expressed by the 67 stakeholders and by each of the three groups. The significance of the difference between sex categories and between services for categories with more than two services was

tested using the non-parametric Friedman test followed by Wilcoxon Post hoc test at $p<0.05$. For categories with only two services, the significance of the difference was tested using Wilcoxon test at $p<0.05$. Different letters indicate significant differences between categories and between services for a same category. For a given category, services with the highest weight are highlighted in bold. AMP: aromatic and medicinal plants.

\begin{tabular}{|c|c|c|c|c|c|c|c|c|c|}
\hline \multirow{2}{*}{ Category } & \multirow[b]{2}{*}{ All } & \multicolumn{3}{|c|}{ Stakeholder groups } & \multirow{2}{*}{ Service } & \multirow{2}{*}{ All } & \multicolumn{3}{|c|}{ Stakeholder groups } \\
\hline & & $\begin{array}{c}\text { Scientists \& } \\
\text { managers }\end{array}$ & Collaborators & Users & & & $\begin{array}{c}\text { Scientists \& } \\
\text { managers }\end{array}$ & Collaborators & Users \\
\hline Regulating & $0.232^{\mathrm{a}} \pm 0.008$ & $0.222^{\mathrm{a}} \pm 0.017$ & $0.232^{\mathrm{a}} \pm 0.016$ & $0.240^{\mathrm{a}} \pm 0.012$ & $\begin{array}{l}\text { Erosion control } \\
\text { Flood control } \\
\text { Climatic regulation }\end{array}$ & $\begin{array}{l}0.455^{\mathrm{a}} \pm 0.012 \\
0.397^{\mathrm{a}} \pm 0.020 \\
0.148^{\mathrm{b}} \pm 0.015\end{array}$ & $\begin{array}{l}0.502^{\mathrm{a}} \pm 0.037 \\
0.377^{\mathrm{a}} \pm 0.039 \\
0.122^{\mathrm{b}} \pm 0.007\end{array}$ & $\begin{array}{l}0.470^{\mathrm{a}} \pm 0.033 \\
0.381^{\mathrm{a}} \pm 0.034 \\
0.149^{\mathrm{b}} \pm 0.037\end{array}$ & $\begin{array}{l}0.413^{\mathrm{a}} \pm 0.032 \\
0.422^{\mathrm{a}} \pm 0.032 \\
0.165^{\mathrm{b}} \pm 0.024\end{array}$ \\
\hline Supporting & $0.209^{a} \pm 0.008$ & $0.195^{\mathrm{a}} \pm 0.0134$ & $0.204^{\mathrm{ab}} \pm 0.018$ & $0.222^{\mathrm{a}} \pm 0.010$ & $\begin{array}{l}\text { Soil fertility } \\
\text { Primary production }\end{array}$ & $\begin{array}{l}0.598^{\mathrm{a}} \pm 0.032 \\
0.402^{\mathrm{b}} \pm 0.032\end{array}$ & $\begin{array}{l}0.517 \pm 0.064 \\
0.482 \pm 0.064\end{array}$ & $\begin{array}{l}0.612 \pm 0.061 \\
0.388 \pm 0.061\end{array}$ & $\begin{array}{l}0.643^{\mathrm{a}} \pm 0.046 \\
0.357^{\mathrm{b}} \pm 0.046\end{array}$ \\
\hline Provisioning & $0.179^{b} \pm 0.008$ & $0.175^{\mathrm{ab}} \pm 0.018$ & $0.176^{\mathrm{b}} \pm 0.013$ & $0.183^{b} \pm 0.011$ & $\begin{array}{l}\text { Water retention } \\
\text { Food supply } \\
\text { Biomass production } \\
\text { AMP supply } \\
\text { Forage productivity }\end{array}$ & $\begin{array}{l}0.429^{\mathrm{a}} \pm 0.010 \\
0.262^{\mathrm{b}} \pm 0.012 \\
0.110^{\mathrm{c}} \pm 0.009 \\
0.103^{\mathrm{c}} \pm 0.010 \\
0.097^{\mathrm{c}} \pm 0.007\end{array}$ & $\begin{array}{l}0.439^{a} \pm 0.019 \\
0.194^{b} \pm 0.023 \\
0.100^{c} \pm 0.016 \\
0.158^{c} \pm 0.028 \\
0.109^{c} \pm 0.016\end{array}$ & $\begin{array}{l}0.434^{\mathrm{a}} \pm 0.020 \\
0.291^{\mathrm{b}} \pm 0.022 \\
0.107^{\mathrm{c}} \pm 0.014 \\
0.071^{\mathrm{c}} \pm 0.011 \\
0.097^{\mathrm{c}} \pm 0.014 \\
\end{array}$ & $\begin{array}{l}0.418^{\mathrm{a}} \pm 0.014 \\
0.287^{\mathrm{b}} \pm 0.016 \\
0.120^{\mathrm{c}} \pm 0.015 \\
0.087^{\mathrm{c}} \pm 0.010 \\
0.088^{\mathrm{c}} \pm 0.008\end{array}$ \\
\hline Biodiversity & $0.138^{\mathrm{c}} \pm 0.008$ & $0.165^{\mathrm{ab}} \pm 0.019$ & $0.130^{\mathrm{C}} \pm 0.013$ & $0.124^{c} \pm 0.011$ & $\begin{array}{l}\text { Species richness } \\
\text { Game abundance } \\
\text { Endemism }\end{array}$ & $\begin{array}{l}0.508^{\mathrm{a}} \pm 0.025 \\
0.252^{\mathrm{b}} \pm 0.017 \\
0.241^{\mathrm{b}} \pm 0.021\end{array}$ & $\begin{array}{l}0.512^{\mathrm{a}} \pm 0.044 \\
0.212^{\mathrm{b}} \pm 0.024 \\
0.276^{\mathrm{a}} \pm 0.042\end{array}$ & $\begin{array}{l}0.533^{\mathrm{a}} \pm 0.050 \\
0.244^{\mathrm{b}} \pm 0.038 \\
0.223^{\mathrm{b}} \pm 0.036\end{array}$ & $\begin{array}{l}0.487^{\mathrm{a}} \pm 0.040 \\
0.284^{\mathrm{b}} \pm 0.026 \\
0.229^{\mathrm{b}} \pm 0.034\end{array}$ \\
\hline Economy & $0.133^{\mathrm{c}} \pm 0.010$ & $0.137^{b c} \pm 0.018$ & $0.126^{\mathrm{c}} \pm 0.018$ & $0.135^{\mathrm{C}} \pm 0.080$ & $\begin{array}{l}\text { Monetary incomes } \\
\text { Employment }\end{array}$ & $\begin{array}{l}0.540 \pm 0.032 \\
0.460 \pm 0.032\end{array}$ & $\begin{array}{l}0.592 \pm 0.061 \\
0.408 \pm 0.061\end{array}$ & $\begin{array}{l}0.625^{\mathrm{a}} \pm 0.056 \\
0.375^{\mathrm{b}} \pm 0.056\end{array}$ & $\begin{array}{l}0.443 \pm 0.047 \\
0.556 \pm 0.047\end{array}$ \\
\hline Culture & $0.110^{c} \pm 0.008$ & $0.106^{\mathrm{c}} \pm 0.014$ & $0.132^{\mathrm{C}} \pm 0.017$ & $0.096^{\mathrm{C}} \pm 0.058$ & $\begin{array}{l}\text { Traditional value } \\
\text { Aesthetic value }\end{array}$ & $\begin{array}{l}0.639^{\mathrm{a}} \pm 0.029 \\
0.361^{\mathrm{b}} \pm 0.029\end{array}$ & $\begin{array}{l}0.570 \pm 0.058 \\
0.430 \pm 0.058\end{array}$ & $\begin{array}{l}0.646^{\mathrm{a}} \pm 0.054 \\
0.354^{\mathrm{b}} \pm 0.054\end{array}$ & $\begin{array}{l}0.682^{\mathrm{a}} \pm 0.041 \\
0.318^{\mathrm{b}} \pm 0.041\end{array}$ \\
\hline
\end{tabular}




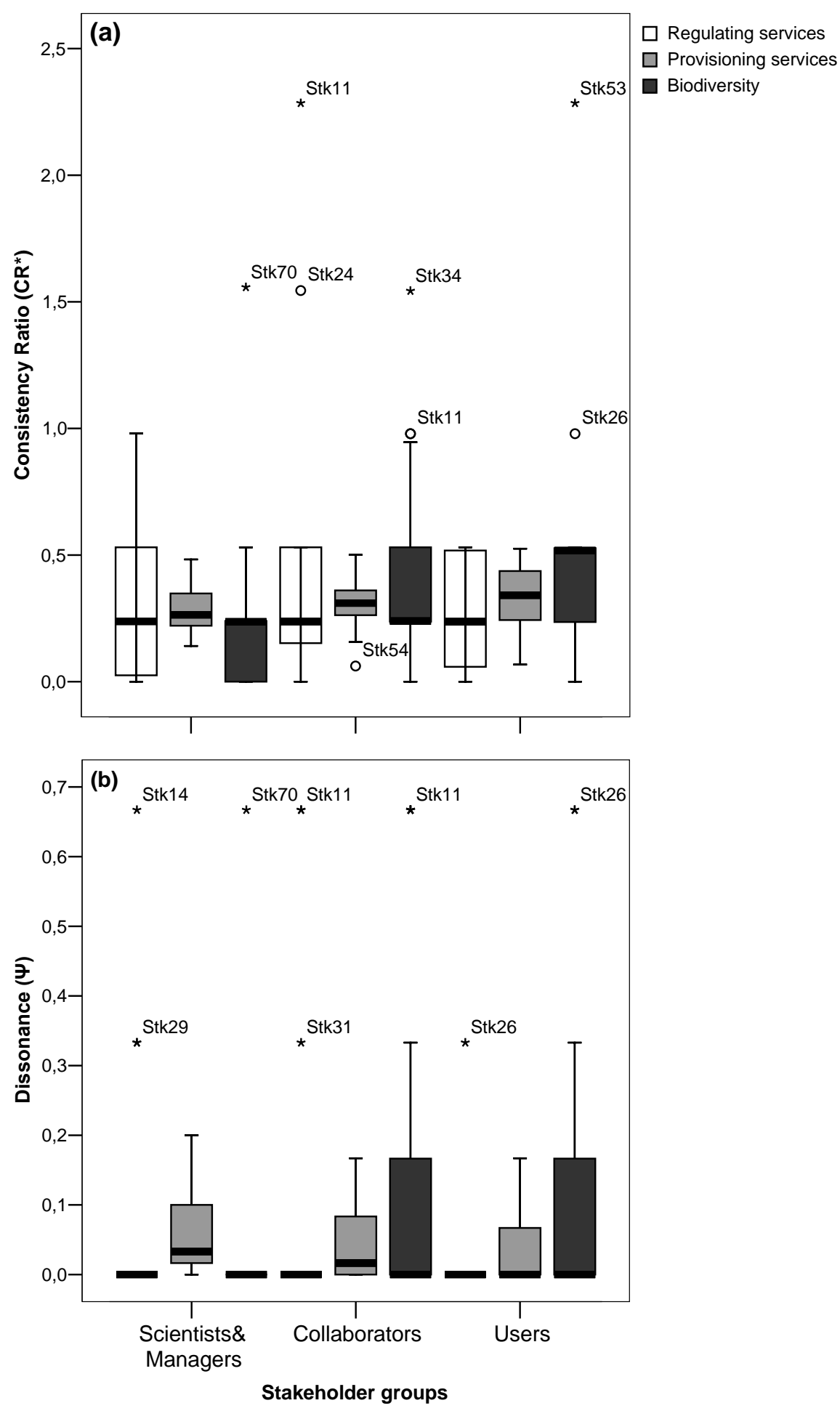

Figure 3. Boxplots describing the consistency ratio values $\left(\mathrm{CR}^{\star}\right)$ and the dissonance value $(\Psi)$ corresponding to pairwise comparisons of regulating and provisioning services and biodiversity. Results are shown for each of the three groups of stakeholders. Hollow circles denote outliers and asterisks denote extreme inconsistencies. 


\section{Acknowledgements}

The research was carried out in the University of Abdelmalek Essaadi (Tétouan, Morocco) and the University of Alicante (Spain) and was funded by the projects SEMER (AECID: Agencia Española de Cooperación Internacional para el Desarrollo, Programa de Cooperación Interuniversitaria AECI-PCI AP/040315/11), RESEP2B (University of Alicante) and UNCROACH (Spanish Ministry of Science and Innovation; CGL2011-30581-C02-01), in collaboration with the Forest Administration of Al Hoceima in $\mathrm{N}$ Morocco. We thank all stakeholders especially the associations RODPAL, MPDL and AZIR for their help in different phases of the study.

\section{Bibliography:}

Accorsi, R., Apostolakis, G., Zio, E., 1999. Prioritizing stakeholder concerns in environmental risk management. J. Risk Res. 2 (1), 11-29.

Al Karkouri, J., 2003. Dégradation du milieu naturel dans le bassin de Béni Boufrah (Rif Central Maroc) : analyse des facteurs et des processus, essai de quantification et modélisation spatiale. Thèse doct. d'Etat, Université Mohamed V, Faculté des Lettres, $392 \mathrm{p}$.

Al Karkouri, J., Watfeh, A., Aderghal, M., 2002. Techniques de conservation de l'eau et des sols dans une zone semi-aride méditerranéenne du Rif central (vallée de Béni Boufrah). Bull. Rés. Eros. 21, 5680.

Al karkouri, J., Laouina, A., Watfeh, A., Aderghal, M., 2006. Gestion conservatoire des eaux et des sols dans le basin versant de Béni Boufrah (Rif Central, Maroc). In: Roose, E., Albergel, J., De Noni, Laouina, A., Sabir, M. (Eds) : Efficacité de la gestion de l'eau et de la fertilité des sols en milieux semi-arides : actes de la session VII organisée par le réseau E-GCES au sein de la conférence ISCO de Marrakech, Maroc.

Ali, I., Cook, W., Kress, M., 1986. On the Minimum Violations Ranking of a Tournament, Manag. Sci. 32 (6), 660-672.

Anton, C., Musche, M., Young, J., Harrison, P.A., Feld, C.K., Harrington, R., Haslett, J.R., Pataki, G., Rounsevell, M.D.A., Paulo Sousa, J., Sykes, M.T., Watt, A., Settele, J., 2010. Research needs for incorporating the ecosystem services approach into EU biodiversity conservation policy. Biodiversity and Conservation 19, 2979-2994.

Avril, P., 1966. Vocation des terrains dans le cadre du développement économique et rural du Rif occidental au Maroc. Pédologie XVI (2), 143-166.

Bautista, S., Orr, B.J., 2011. IAPro, PRACTICE Integrated Assessment Protocol Participatory. Deliverable D2.3. Available in: http://practice-netweb.eu/sites/default/files/D2 3 PRACTICE IAPro.pdf

Benbrahim, K.F., Ismaili, M., Benbrahim, S.F., Tribak, A., 2004. Problèmes de dégradation de l'environnement par la désertification et la déforestation: impact du phénomène au Maroc. Sécheresse 15, 307-320.

Boujrouf, S., 1996. La montagne dans la politique d'aménagement du territoire du Maroc. Revue de géographie alpine. 84 (4), 37-50.

Bozóki, S., Rapcsák, T., 2008. On Saaty's and Koczkodaj's inconsistencies of pairwise comparison matrices. J. Global Optim. 42, 157-175.

Bullock, J.M., Aronson, J., Newton, A.C., Pywell, R.F., Rey-Benayas, J.M., 2011. Restoration of ecosystem services and biodiversity: conflicts and opportunities. Trends Ecol. Evol. 26 (10), 514-549.

Butchart, S.H.M. et al., 2010. Global biodiversity: indicators of recent declines. Science 328, 11641168.

Butzer, K., 2005. Environmental history in the Mediterranean world: cross disciplinary investigation of cause-and-effect for degradation and soil erosion. J. Archaeol. Sci. 32: 1773-1800.

Castro, A.J., Martín-López, B., García-Llorente, M., Aguilera, P.A., López, E., Cabello, J., 2011. Social preferences regarding the delivery of ecosystem services in a semiarid Mediterranean region. J. Arid. Environ. 75, 1201-1208. 
Chalmers, N., Fabricus, C., 2007. Expert and Generalist Local Knowledge about Land-cover Change on South Africa's Wild Coast: Can Local Ecological Knowledge Add Value to Science? Ecol. Soc. 12, 10-25.

De Feo, G., De Gisi, S., 2010. Using an innovative criteria weighting tool for stakeholders involvement to rank MSW facility sites with the AHP. Waste manage. 30, 2370-2382.

De Groot, R.S, Alkemade, R., Braat, L., Hein, L., Willemen, L., 2010. Challenges in integrating the concept of ecosystem services and values in landscape planning, management and decision making. Ecol. Complex. 7, 260-272.

Derak, M., Cortina, J., 2014. Multi-criteria participative evaluation of Pinus halepensis plantations in a semiarid area of southeast Spain. Ecol. Indic. 43, 56-68.

Elbroch, M., Mwampamba, T.H., Santos, M.J., Zylberberg, M., Liebenberg, L., Minye, J., Mosser, C., Reddy, E., 2011. The Value, Limitations, and Challenges of Employing Local Experts in Conservation Research. Conserv. Biol. 25:1195-1202.

El Khattabi, J., 2001. Démarche méthodologique pluridisciplinaire intégrant une approche transversale pour l'étude des instabilités de versants : application aux versants du Rif Central (Maroc), Thèse de Doctorat, Univ. Artois, 258p.

Fontana, V., Radtke, A., Fedrigotti, V.B., Tappeiner, U., Tasser, E. Zerbe, S., Buchholz, T., 2013. Comparing land-use alternatives: Using the ecosystem services concept to define a multi-criteria decision analysis. Ecol. Econ. 93, 128-136.

Forman, E., Peniwati, K., 1998. Aggregating individual judgments and priorities with the analytic hierarchy process. Eur. J. Oper. Res. 108, 165-169.

Freeman, R.E., 1984. Strategic Management: a Stakeholder Approach. Pitman, Boston.

Funtowicz, S.O., Ravetz, J.R., 2000. La ciencia posnormal: ciencia con la gente, Barcelona, Icaria.

Gadgil, M., Olsson, P., Berkes, F. Folke, C., 2003. Exploring the role of local ecological knowledge in ecosystem management: three case studies. In Berkes, F., Colding, J., Folke, C. editors. Navigating social-ecological systems: building resilience for complexity and change. Cambridge University Press, Cambridge, UK.

García-Llorente, M., Martín-López, B., Iniesta-Arandia, I., López-Santiago, C.A., Aguilera, P.A., Montes, C., 2012. The role of multi-functionality in social preferences toward semi-arid rural landscapes: An ecosystem service approach. Environ. Sci. Policy 19-20, 136-146.

Goma, H.C., Rahim, K., Nangendo, G., Riley, J., Stein, A., 2001. Participatory studies for agroecosystem evaluation. Agr. Ecosyst. Environ. 87, 179-190.

Gonzalez, C., Clemente, A., Nielsen, K.A., Branquinho, C., Dos Santos, R.F., 2009. Human-Nature Relationship in Mediterranean Streams: Integrating Different Types of Knowledge to Improve Water Management. Ecol. Soc. 14: 35. Available in : http://www.ecologyandsociety.org/vol14/iss2/art35/.

International Bank for Reconstruction and Development 2006. Approches participatives au Maroc: Bilan de l'expérience et recommandations pour la mise en œuvre de I'Initiative Nationale de $\begin{array}{lll}\text { Développement Humain } & \text { (INDH). } \\ \text { http://www.albacharia.ma/xmlui/handle/123456789/30304. }\end{array}$

Jungerius, P.D., De Mas, P., Wusten, H.V.D., 1985. Land evaluation: a part of the decision environment of the subsistence farmer in the Rif mountains, Morocco. In: Land evaluation for land-use planning and conservation in sloping areas Proceedings ; ILRI Publication (Netherlands), no. 40; International Workshop on Land Evaluation for Land-Use Planning and Conservation in Sloping Areas, Enschede (Netherlands), 17-21.

Kangas, J., 1994. An approach to public participation in strategic forest management planning. Forest. Ecol. Manag. 70, 75-88.

Kendall, M., Smith, B., 1940. On the Method of Paired Comparisons, Biometrika 31, 324-345.

Khater, C., Raevel, V., Sallantin, J., Thompson, J.D., Hamze, M., Martín, A., 2012. Restoring Ecosystems Around the Mediterranean Bassin: Beyond the Frontiers of Ecological Science. Restor. Ecol. 20 (1), 1-6. 
Lamarque, P., Tappeiner, U., Turner, C., Steinbacher, M., Bardgett, R.D., Szukics, U., Schermer, M., Lavorel, S., 2011. Stakeholder perceptions of grassland ecosystem services in relation to knowledge on soil fertility and biodiversity. Reg. Environ. Change 11, 791-804.

Laouina, A., Roose, E., Sabir, M., 2006. Spatialisation de la gestion conservatoire des eaux et des sols au maroc, les facteurs écologiques sociaux et culturels. In: Roose, E., Albergel, J., De Noni, Laouina, A., Sabir, M. (Eds) : Efficacité de la gestion de l'eau et de la fertilité des sols en milieux semi-arides : actes de la session VII organisée par le réseau E-GCES au sein de la conférence ISCO de Marrakech, Maroc.

Martín-López, B., Montes, C., Benayas, J., 2007a. Influence of user characteristics on valuation of ecosystem services in Doñana Natural Protected Area (south-west Spain). Environ Conserv 34: 215224.

Martín-López, B., Iniesta-Arandia, I., García-Llorente M., Palomo, I., Casado-Arzuaga, I., García Del Amo, D., Gómez-Baggethun, E., Oteros-Rozas, E., Palacios-Agundez, I., Willaarts, B., González, J.A., Santos-Martín, F., Onaindia, M., López-Santiago, C., Montes, C., 2012. Uncovering Ecosystem Service Bundles through Social Preferences. Plos ONE 7, 1-11.

Mauro, F., Hardison, P. D., 2000. Traditional knowledge of indigenous and local communities: international debate and policy initiatives. Ecol. Appl. 10, 1263-1269.

Malczewski, J., 1999. GIS and Multi-criteria Decision Analysis. John Wiley y Sons, Inc., USA.

McNeely, J.A., 2003. Biodiversity in arid regions: values and perceptions. J. Arid. Environ. 54, 61-70.

Melhaoui,Y., 2002. Protection et gestion participative des écosystèmes forestiers du RIF. Deuxième atelier international sur la foresterie participative en Afrique, Arusha (Tanzanie), 331-339.

Menzel, S., Teng, J., 2009. Ecosystem Services as a Stakeholder-Driven Concept for Conservation Science. Conserv. Biol. 24 (3), 907-909.

Millennium Ecosystem Assessment (MEA), 2005. Ecosystems and Human Well-Being: Current State and Trends. Washington, DC: Island.

Moroccan Forest Ministry, 1999. National Forest Program, Final Report. Rabat, Morocco.

Moroccan General Census, 2004. Moroccan High Planning Commissary. Available in : http://cartes.hcp.ma/identify.asp?action=Identify\&

Moufaddal, M., 2007. Les tendances en matière de propriété forestière, de mode de faire valoir des resources forestières et des arrangements institutionnels. Cas du Maroc. Rome, FAO.

Mulas, M., Bellavite, D., Lubino, M., Belkheiri, O., Enne, G., 2012. Participatory approach for integrated development and management of North African marginal zones: demonstrative plan to fight desertification in Morocco and Tunisia. Italian Journal of Agronomy 7, 351-354.

Nadasny, P., 1999. The politics of TEK: power and the "integration" of knowledge. Arctic Anthropol. 36, 1-18.

Noble, B.F., 2004. Strategic environmental assessment quality assurance: evaluating and improving the consistency of judgments in assessment panels. Environ. Impact Asses. 24, 3-25.

Pascon, P., Wusten, H.V.D., 1983. Béni Boufrah, Essai d'écologie sociale d'une vallée rifaine. Institut Universitaire de Recherche Scientifique, Rabat, Maroc.

Payton, R.W., Barr, J.J.F., Martín, A., Sillitoe, P., Deckers, J.F., Gowing, J.W., Hatibu, N., Naseem, S.B., Tenywa, M. Zuberi, M.I., 2003. Contrasting approaches to integrating indigenous knowledge about soils and scientific soil survey in East Africa and Bangladesh. Geoderma 111, 355-386.

Perry, J., 2014. The FAO Forestry Division and the Development of Morocco's Rif. Fribourg workshop draft. Avaialable in: https://lettres.unifr.ch/fileadmin/Documentation/Departements.

Reed, M.S., 2008. Stakeholders participation for environmental management: a literature review. Biol. Conserv. 141, 2417-2431.

Regato, P., Colomer, R., Berrahmouni, N., Badalotti, A., Dia, A.O., 2009. La Restauration des Paysages Forestiers au Maroc, Manuel de bonnes pratiques. WWF Méditerranée, Rome.

Regional Forest Administration of NE Morocco, 2012. Management study of Béni Boufrah forest. 
Reyers, B., O'Farrell, P.J., Cowling, R.M., Egoh, B.N., Le Maitre, D.C., Vlok, J.H.J., 2009. Ecosystem services, land-cover change, and stakeholders: finding a sustainable foothold for a semiarid biodiversity hotspot. Ecol. Soc. 14 (1), 38-61.

Rodríguez, J.J., Beard. T.D.J., Bennett. E.M., Cumming, G.S., Cork. S.J., et al., 2006. Trade-offs across space, time, and ecosystem services. Ecol. Soc. 11: 28.

Rodríguez-Aizpeolea, J., Lasanta-Martínez, T., 1992. Los bancales abandonados en la montaña mediterránea: una revisión bibliográfica. Pirineos 139:105-123.

Romero, C., 1996. Análisis de las decisiones multi-criterio, №14, Madrid: Isdefe.

Saaty, T.L., 1980. The Analytic Hierarchy Process. McGraw- Hill, New York.

Scheele, D.S., 1975. Reality construction as a product of Delphi interaction. In: Linstone HA, Turoff M, editors. The Delphi method: techniques and applications. Boston, MM: Addison-Wesley.

Siraj, S., 2011. Preference elicitation from Pairwise comparisons in multi-criteria decision making. PhD Thesis. School of Computer Science, University of Manchester, UK.

Society for Ecological Restoration. International Science and Policy Working Group. 2004. The SER International Primer on Ecological Restoration.

Sodhi, N.S., Lee, T.M., Sekercioglu, C.H., Webb. E.L., Prawiradilaga, D.M., Lohman, D.J., Pierce, N.E., Diesmos, A.C., Rao, M., Ehrlich, P.R., 2010. Local people value environmental services provided by forested parks. Biodivers. Conserv. 19, 1175-1188.

Strager, M.P., Rosenberger, R.S., 2006. Incorporating stakeholders preferences for land conservation: weights and measures in spatial MCA. Ecol. Econ. 57, 627-639.

Sugden, R., 1985. Why be Consistent? A Critical Analysis of Consistency Requirements in Choice Theory, Economica 52 (206), 167-183.

Wilcox, D., 2003. The Guide to Effective Participation (online). http://www.partnerships.org.uk/guide. 